\title{
Intervenção ergonômica em uma fábrica de ônibus: montagem de poltronas e painéis de controle
}

Tarcisio Abreu Saurin, Dr.

Núcleo de Design, Ergonomia e Segurança no Trabalho, Programa de Pós-Graduação em Engenharia de Produção da UFRGS tasaurin@producao.ufrgs.br

Lia Buarque de Macedo Guimarães, PhD, CPE

Núcleo de Design e Ergonomia e Segurança no Trabalho

Programa de Pós-Graduação em Engenharia de Produção da UFRGS

lia@producao.ufrgs.br

Esse trabalho relata os resultados de uma intervenção ergonômica em uma fábrica de ônibus no Rio Grande do Sul. No setor de fabricação de poltronas, a intervenção envolveu as etapas de apreciação e diagnóstico ergonômico, tendo sido priorizados três postos de trabalho: colocação de capas nas poltronas, montagem da estrutura metálica da poltrona e montagem do assento. Avaliações de esforço físico por meio de registro de freqüência cardíaca e avaliações posturais por meio do método OWAS foram conduzidas nesses três postos, confirmando a existência de constrangimentos ergonômicos relevantes. As propostas de melhoria no setor de poltronas incluem a realização da costura das capas por meio de máquinas de costura e a adoção de conceitos de manufatura celular, na qual os trabalhadores realizariam todas as etapas do ciclo de montagem da poltrona. Na atividade de montagem de painéis, a qual era realizada totalmente interna ao ônibus, as etapas de apreciação e diagnóstico indicaram a existência de sérios constrangimentos posturais. Uma estação de submontagem externa ao ônibus foi testada, implicando em melhores posturas do montador e aumento de produtividade, quando comparada à situação existente de montagem integral do painel dentro do ônibus. As melhorias propostas foram parcialmente embasadas por uma visita à fábrica alemã de um dos principais concorrentes da fábrica brasileira na qual ocorreu o estudo.

Palavras-chave: avaliação postural; esforço físico; ônibus

\section{Ergonomic intervention in a bus manufacturing company: seat and panel of control assembly}

This paper presents the results of an ergonomic intervention in a bus manufacturing company in the State of Rio Grande do Sul. In the seat manufacturing department the intervention has involved a preliminary survey of ergonomic constraints followed by a more detailed diagnosis. Based on this diagnosis, three work stations were prioritized in this department: placement of the cover on the seats, assembly of the seats' metal frame and seat assembly. Physical workload assessments through heart rate measurements and postural assessments through the OWAS method were conducted in those work stations. The results pointed out relevant ergonomic constraints in all of them. In the panel of control assembly work station, which was located inside the bus, the ergonomic diagnosis indicated awkward postures as the main problem. A new work station outside the bus was tested and it was found advantageous in comparison with the internal assembly. In addition to productivity improvement, the awkward postures were substantially reduced. The proposed improvements were partly based on a visit to a bus factory in Germany, which is one of the main competitors of the Brazilian factory in which this study took place.

Keywords: posture assessment; physical workload; bus 


\section{Introdução}

Dentre os problemas mais freqüentemente encontrados no diagnóstico ergonômico de processos produtivos estão os Distúrbios Osteomusculares Relacionados ao Trabalho (DORT), os quais vêm gerando custos não só para as empresas mas para toda a sociedade. De acordo com o INSS (1986), as doenças do sistema osteomuscular são a principal causa de auxílio-doença custeado pela Seguridade Social ( $10,3 \%$ dos benefícios concedidos) e a terceira maior causa de aposentadoria por invalidez ( $9,7 \%$ dos benefícios concedidos). Em países desenvolvidos a situação é similar, sendo que nos Estados Unidos os custos diretos das doenças musculoesqueléticas situam-se em torno de US\$20 bilhões ao ano e na Holanda o custo destas patologias oscila entre $0,5 \%$ e $2,0 \%$ do Produto Interno Bruto (LAGERLOF, 2000).

Em particular, as atividades de montagem, caracterizadas por uso intensivo de mão-de-obra, estão estreitamente relacionadas à alta incidência de DORT. Dentro do processo produtivo, a montagem geralmente é o elo mais fraco, por consumir parte substancial dos custos e do tempo total de produção (RAMPERSAD, 1994). Apesar disto, pouca atenção é dispensada às questões ergonômicas neste tipo de atividade. Contudo, quando os problemas ergonômicos são identificados, muitas vezes são realizadas ações pontuais de melhoria (por exemplo, ajuste nas dimensões de uma bancada) ou medidas que atuem apenas sobre os sintomas (por exemplo, um programa de ginástica laboral, isoladamente de outras ações preventivas), dando-se pouca atenção às suas causas fundamentais.

Tendo em vista o combate às causas raízes, são necessárias ações que considerem o sistema sóciotécnico dentro do qual o trabalho é realizado, podendo incluir medidas que vão desde o reprojeto de processos e produtos até mudanças no layout e capacitação dos trabalhadores (HENDRICK e

KLEINER, 2001; RASMUSSEN, 1997). Com base nesses pressupostos, esse trabalho relata uma intervenção ergonômica realizada em uma fábrica de ônibus para transporte urbano e rodoviário, os quais são vendidos para o mercado interno e exportados para diversos países. Neste artigo, são apresentadas as intervenções realizadas no setor de fabricação de poltronas e no posto de trabalho de montagem de painéis.

\section{Método de pesquisa}

\subsection{Visão geral do método de análise do trabalho}

Devido à alta incidência de DORT em trabalhadores de diversos setores, assim como tendo em vista o atendimento de exigências da norma OHSAS 18001 (Occupational Health and Safety Management Systems), a qual requer a consideração de requisitos ergonômicos no processo produtivo, em fevereiro de 2002 a empresa estabeleceu uma parceria com o PPGEP/UFRGS para o desenvolvimento de pesquisas em ergonomia aplicadas ao seu processo de produção.

A intervenção ergonômica foi conduzida segundo o método de Análise Macroergonômica do Trabalho (AMT) proposto por Guimarães (1999), que consiste das etapas de lançamento do projeto, apreciação ergonômica, diagnóstico, proposição de soluções, validação e detalhamento. No setor de fabricação de poltronas, escolhido em função do expressivo número de atendimentos de trabalhadores com queixas de lombalgias (a empresa não permitiu a divulgação das estatísticas), a intervenção restringiu-se às etapas de apreciação e diagnóstico ergonômico. A apreciação ergonômica contempla um levantamento inicial dos postos sob avaliação e, após análise preliminar dos dados, uma discussão dos problemas junto com o comitê de ergonomia da empresa e, principalmente, com os trabalhadores. Com base nesta discussão, os postos e/ou aspectos mais importantes da situação apresentada são selecionados para análise mais detalhada que configura o diagnóstico.

Já na atividade de montagem de painéis, que na realidade constitui um posto de trabalho ao longo da linha de montagem final dos veículos, a intervenção abrangeu ainda as etapas de proposição de soluções e validação. A demanda pelo estudo na montagem dos painéis também decorreu da alta 
incidência de DORT e acidentes de trabalho nesta atividade, conforme dados disponibilizados pelo SESMT (Serviço Especializado em Segurança e Medicina do Trabalho) da empresa.

De modo complementar às atividades citadas acima, foi realizada uma visita a outra empresa fabricante de ônibus, com o objetivo de identificar boas práticas que pudessem ser adaptadas. A empresa visitada situa-se na Alemanha, sendo uma das principais concorrentes da empresa brasileira na qual ocorreu o estudo. A visita ocorreu ao longo de um dia e contou com a participação de um dos autores deste artigo.

\subsection{Apreciação ergonômica}

$\mathrm{Na}$ etapa de apreciação, os seguintes instrumentos de coleta de dados foram utilizados: entrevistas semi-estruturadas com trabalhadores e gerentes; observação direta; filmagens; aplicação de questionários.

No setor de poltronas, as entrevistas foram realizadas junto a dezoito funcionários ( $20 \%$ da população), individualmente ou em duplas, sendo que a duração das entrevistas foi de aproximadamente vinte minutos. Não foi possível entrevistar um maior número de pessoas simultaneamente visto que a gerência do setor alegou que isso prejudicaria o ritmo de produção. Na linha de montagem foram entrevistados cento e cinqüenta e um trabalhadores ( $30 \%$ da população) em grupos formados geralmente por quatro pessoas, sendo que as entrevistas com cada grupo tiveram duração de trinta a quarenta minutos. De acordo com o proposto no método da AMT, as entrevistas não seguem um roteiro rígido de questões. Os funcionários são apenas solicitados a falar sobre os aspectos positivos e negativos de seu trabalho como um todo (não apenas sobre suas tarefas específicas), não havendo qualquer tipo de indução. Cabe salientar que os funcionários são estimulados a apresentar sugestões para resolução dos problemas comentados. As respostas das entrevistas foram tabuladas em planilha Excel por ordem de menção e analisadas pela equipe de pesquisadores. Foram expurgadas as informações não pertinentes e agrupadas as respostas por afinidade, ou seja, as respostas semelhantes foram consideradas como um mesmo item de demanda ergonômica (IDE).

Com base nos resultados qualitativos das entrevistas, foram elaborados dois questionários (um relativo ao setor de poltronas e outro à linha de montagem) para que os trabalhadores apontassem quais demandas deveriam ser priorizadas no desenvolvimento de ações de melhoria. No questionário também foram incluídas questões referentes a problemas identificados pelos pesquisadores e não mencionados nas entrevistas. A opinião de cada sujeito com relação a cada questão é quantificada por meio de uma escala de avaliação contínua, sugerida por Stone et al. (1974). Essa escala possui duas âncoras nas extremidades (insatisfeito e satisfeito) e uma âncora no centro (neutro). A escala tem 15 $\mathrm{cm}$ e ao longo dela o sujeito deverá marcar a sua percepção sobre o item, sendo que a intensidade de cada resposta poderá variar entre 0 e 15 . Enquanto no setor de poltronas sessenta e quatro funcionários responderam aos questionários, na linha de montagem sessenta e três pessoas responderam. Os questionários não requerem o nome dos respondentes. Os resultados foram tabulados e priorizados em função do nível de satisfação utilizando o software SPSS 10.0 FOR WINDOWS.

\subsection{Diagnóstico}

No setor de fabricação de poltronas, a partir dos resultados das entrevistas e questionários, foram identificados três postos de trabalho críticos do ponto de vista ergonômico, merecendo uma investigação mais detalhada: ensacamento, pré-montagem e montagem do assento. Nesses postos, foi realizada uma avaliação da carga física postural e uma avaliação da carga fisiológica por meio de pulsos de trabalho. Já no posto de montagem de painéis, apenas a avaliação postural foi realizada, visto os constrangimentos posturais serem notadamente os mais relevantes. 


\subsubsection{Avaliação da carga física postural}

A avaliação das posturas assumidas durante o trabalho foi realizada com a ferramenta computacional WinOWAS ${ }^{\circledR}$ (KIVI e MATILLA, 1991). Essa ferramenta baseia-se no método OWAS (KARHU et al., 1977) que, com base nas posturas de trabalho e na força exercida durante uma ação específica, classifica o grau de risco da postura em quatro categorias:

a) categoria 1: a postura é normal, não sendo exigida nenhuma medida corretiva;

b) categoria 2: a carga física da postura é levemente prejudicial, sendo necessário adotar medidas para mudar a postura em um futuro próximo;

c) categoria 3: a carga física da postura é prejudicial, sendo necessárias medidas para mudar a postura o mais rápido possível;

d) categoria 4: a carga física da postura é extremamente prejudicial, sendo necessárias medidas imediatas para mudar as posturas.

O trabalho em cada posto foi gravado em fita de vídeo, permitindo avaliações posturais a cada trinta segundos, conforme preconizado pelo método WinOWAS ${ }^{\circledR}$. Foram realizadas cem observações, com o registro das costas, braços, pernas e forças envolvidas nas atividades de cada posto.

\subsubsection{Avaliação da carga fisiológica por pulso de trabalho}

A carga fisiológica de trabalho nos postos de ensacamento, montagem do assento e pré-montagem foi avaliada por cálculo indireto, com base na freqüência cardíaca (FC) registrada durante o trabalho. Nos postos de ensacamento e pré-montagem, o registro da $\mathrm{FC}$ foi realizado por meio de monitores portáteis, marca Polar, modelo S610. Esse aparelho é composto por uma unidade transmissora, com eletrodos fixados junto ao tórax, abaixo dos músculos torácicos, e fixados por uma tira elástica ajustável. Os eletrodos detectam os sinais advindos do coração que são, então, transmitidos a uma unidade receptora de pulso para gravação e análise. As informações são registradas e podem ser enviadas para um software que processa os dados estatisticamente e os transforma em representações gráficas.

No posto de montagem do assento, o modelo de monitor de FC não possuía interface com o computador. Assim, foram realizadas leituras dos batimentos em intervalos de cinco minutos. A Tabela 1 apresenta a caracterização básica dos funcionários avaliados. Após a colocação dos eletrodos em cada funcionário, os mesmos permaneceram cerca de quinze minutos sentados, para que então fosse medida a FC de repouso (pulso de repouso). A seguir, a FC de cada funcionário foi monitorada ao longo de cerca de duas horas de trabalho, sendo feito também o registro das tarefas que cada um desempenhou.

Tabela 1 - Caracterização básica dos trabalhadores submetidos ao registro de freqüência cardíaca

\begin{tabular}{l|llll} 
Trabalhador & Idade & Altura & Peso & Experiência na empresa \\
\hline Ensacamento & 19 & $173 \mathrm{~cm}$ & $86 \mathrm{~kg}$ & 5 anos \\
Pré-montagem & 20 & $193 \mathrm{~cm}$ & $81 \mathrm{~kg}$ & 2,5 anos \\
Montagem do assento & 39 & $164 \mathrm{~cm}$ & $80 \mathrm{~kg}$ & 2 anos
\end{tabular}

\section{Resultados}

\subsection{Setor de fabricação de poltronas}

\subsubsection{O trabalho de fabricação de poltronas}

No setor de fabricação de poltronas, existem duas linhas paralelas de montagem, uma para poltronas de ônibus urbanos e outra para poltronas de ônibus rodoviários. Ao longo de cada linha, existem os seguintes postos de trabalho: pré-montagem da estrutura metálica da poltrona, quando sua base é 
parafusada ao encosto; ensacamento, quando é colocada a capa da poltrona; fechamento do ensacamento e colocação do assento. As atividades realizadas em cada posto possuem pequenas variações em função do modelo de poltrona. Os assentos são produzidos em um mezanino acima das linhas. A Figura 1 resume as tarefas desempenhadas nos postos selecionados para diagnóstico, de acordo com as observações dos pesquisadores. A Figura 2 ilustra esses postos.

\begin{tabular}{|c|c|}
\hline Posto de trabalho & Tarefas \\
\hline Ensacamento & $\begin{array}{l}\text { Com a poltrona já sobre a esteira, o funcionário usa um gabarito metálico para } \\
\text { marcar os locais dos furos para costura da capa do banco. Então, passa cola na } \\
\text { parte superior do banco e passa sabão no mesmo, visando a facilitar o } \\
\text { deslizamento da capa. São feitos furos na espuma do encosto e a capa é } \\
\text { colocada e costurada, de cima para baixo. Em função do desgaste físico, não há } \\
\text { trabalhadores fixos neste posto. }\end{array}$ \\
\hline Pré-montagem & $\begin{array}{l}\text { A estrutura metálica do assento é unida a estrutura metálica do encosto. Além } \\
\text { disso, são colocados o descansa-braços e o cinto de segurança. A mola de ajuste } \\
\text { da inclinação da poltrona é colocada e testada. }\end{array}$ \\
\hline $\begin{array}{l}\text { Montagem do } \\
\text { assento }\end{array}$ & $\begin{array}{l}\text { A poltrona é retirada da esteira e colocada sobre uma plataforma na qual o } \\
\text { assento será encaixado. A seguir, a poltrona é transportada aos carrinhos de } \\
\text { estoque, onde aguarda o deslocamento até o pátio externo para novo estoque } \\
\text { intermediário. }\end{array}$ \\
\hline
\end{tabular}

Figura 1 - Tarefas dos postos de trabalho priorizados, conforme observações dos pesquisadores
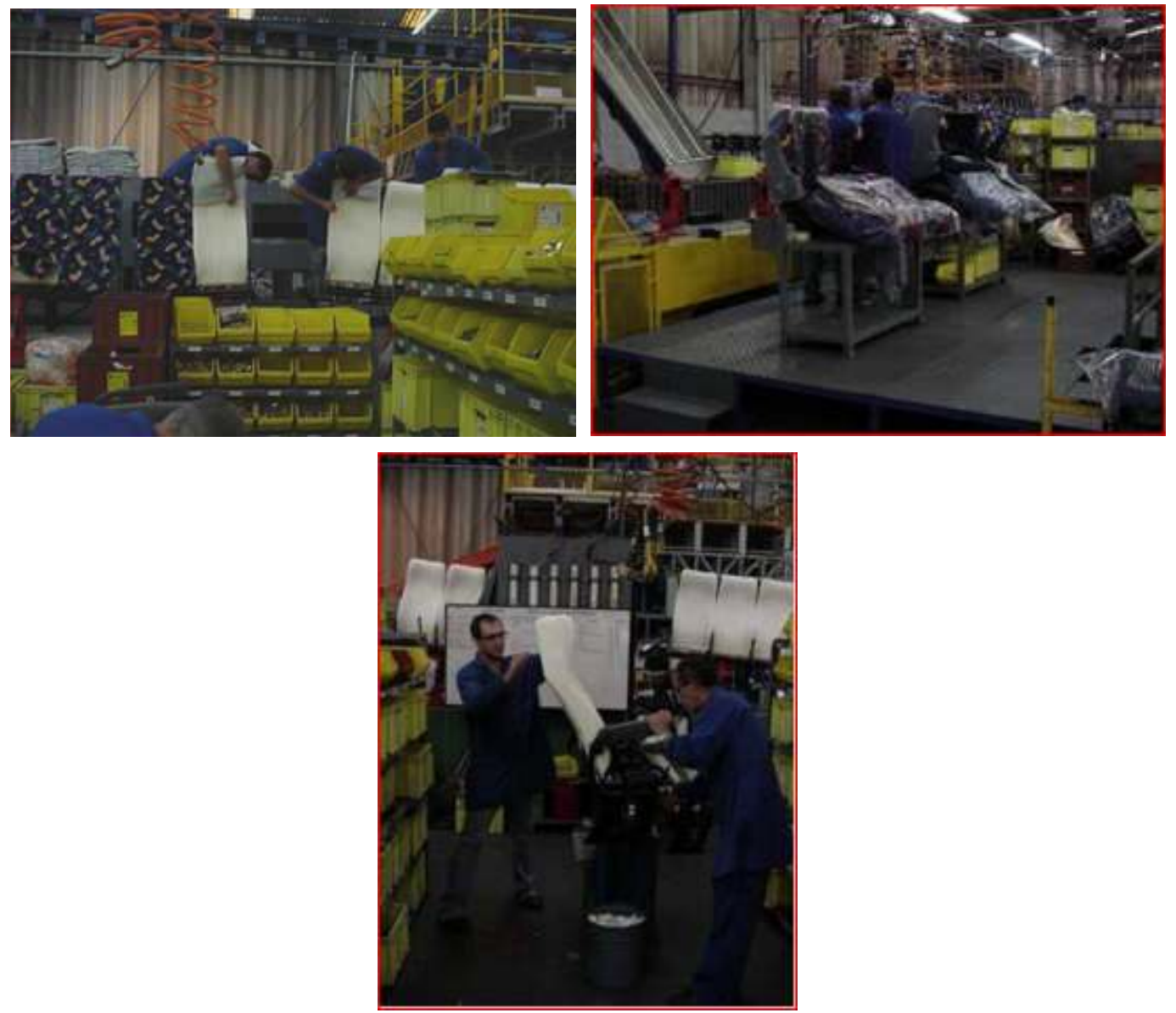

Figura 2 - Ilustração dos postos de trabalho priorizados (em cima à esquerda: ensacamento; em cima à direita: montagem do assento; embaixo: pré-montagem) 


\subsubsection{Entrevistas}

A Figura 3 ilustra os resultados das entrevistas, podendo ser percebido que cerca da metade das reclamações são relativas ao esforço físico excessivo. Por exemplo, houve várias reclamações decorrentes do transporte manual de poltronas, que nos modelos maiores, chegam a pesar mais de 20 $\mathrm{kg}$. No caso da linha de ônibus rodoviários, as poltronas são inicialmente transportadas da esteira para uma bancada na qual o assento será encaixado (ver Figura 2). A seguir, a mesma poltrona é transportada até um carrinho transportador juntamente com várias outras poltronas. Por sua vez, esse carrinho é novamente transportado até o pátio externo do setor, onde aguarda a expedição para a linha de montagem dos ônibus ou para outras fábricas da empresa.

\section{Esforço físico excessivo (transportes)}

1) Muito esforço físico para empurrar carrinhos com poltronas, as rodas travam

2) Esforço físico excessivo para transporte das poltronas desde o fim da linha até o posto de montagem de assento e daí até os carrinhos de estoque

3) O trajeto feito com os carrinhos é muito extenso até o pátio externo (problemas de layout)

Esforço físico excessivo (processamentos)

4) Serviço de ensacamento é muito pesado

5) Serviço de colocação de molas de pressão na base dos assentos é muito pesado

6) Espuma do encosto de alguns carros é dura, dificulta o aparafusamento

7) Colocação do porta-revista exige muito esforço físico

\section{Ferramentas}

8) As ferramentas dos balancins são muito pesadas

9) Muitas ferramentas em precário estado de conservação, não funcionam, não tem força

10) Conflito de ferramentas entre o turno do dia e da noite

\section{Meio ambiente}

11) Fumaça que exala do setor vizinho de soldagem

12) Calor excessivo no posto de ensacamento

Organização do trabalho

13) Necessidade de maior revezamento em todas as tarefas (urbano)

14) Ritmo da esteira é muito forte, especialmente para o serviço de ensacamento

15) Desorganização do estoque de estruturas dos bancos

Figura 3 - Resultados das entrevistas no setor de poltronas

\subsubsection{Questionários}

As percepções dos funcionários foram agrupadas em sete constructos (posto de trabalho, dor e desconforto, ambiente, organização, conteúdo do trabalho, empresa e desgaste físico). As Figuras 4, 5 6 e 7 ilustram os resultados, respectivamente, para os constructos dor e desconforto, grau de cansaço, posto de trabalho e meio ambiente.

De acordo com a Figura 4, a incidência de desconforto e dor ocorre principalmente nas costas, braços e pernas, situações em que os valores médios ultrapassaram a metade da escala. Considerando um nível de confiança de $95 \%$, não houve diferença estatística significativa entre as médias das dores nas costas, braços e pernas, embora exista diferença entre as médias das dores nas costas e braços em relação às médias das demais partes do corpo avaliadas. Com exceção do posto de fechamento do ensacamento, todas as demais atividades são realizadas em pé, havendo constante manuseio de ferramentas e esforço físico intenso, muitas vezes com as costas curvadas. Essas condições explicam a preponderância de dores nos locais mencionados.

No que diz respeito ao grau de cansaço (Figura 5), parece haver esforço físico demasiado em todas as tarefas, uma vez que os valores médios atribuídos ao grau de cansaço ultrapassaram a metade da escala para todos os postos, com exceção do uso de ferramentas suspensas em balancins. Esse posto foi o único cuja média apresentou diferença estatística significativa em relação aos demais, ou seja, 
pode-se dizer que todos os outros postos geram grau de cansaço físico similar na percepção dos trabalhadores. Cabe salientar que, na etapa inicial do estudo, representantes do setor de segurança e saúde suspeitavam que o uso de ferramentas suspensas constituía a tarefa mais desgastante fisicamente e era a principal contribuinte para a incidência de doenças ocupacionais. Embora as percepções quanto ao cansaço gerado nos demais postos sejam iguais, os postos de ensacamento, pré-montagem e montagem do assento foram priorizados na etapa de diagnóstico uma vez que os problemas nos mesmos foram mais enfatizados pelos trabalhadores na etapa de entrevistas.

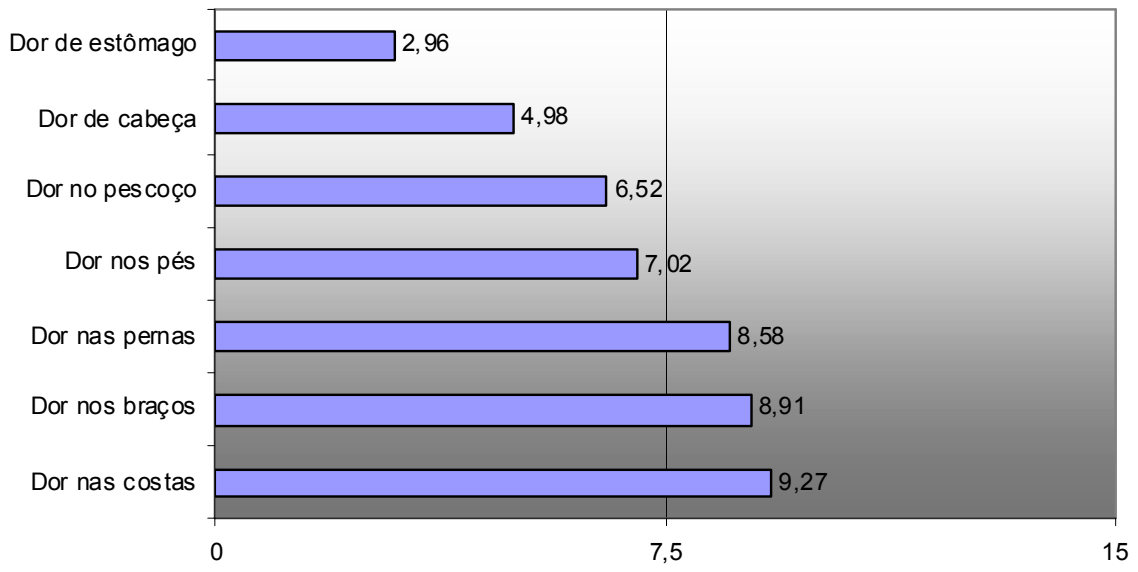

Figura 4 - Resultados dos questionários para o constructo dor e desconforto

Nota: nível de desconforto e dor percebido pelos funcionários $(0=$ nenhuma dor, $15=$ muita dor $)$

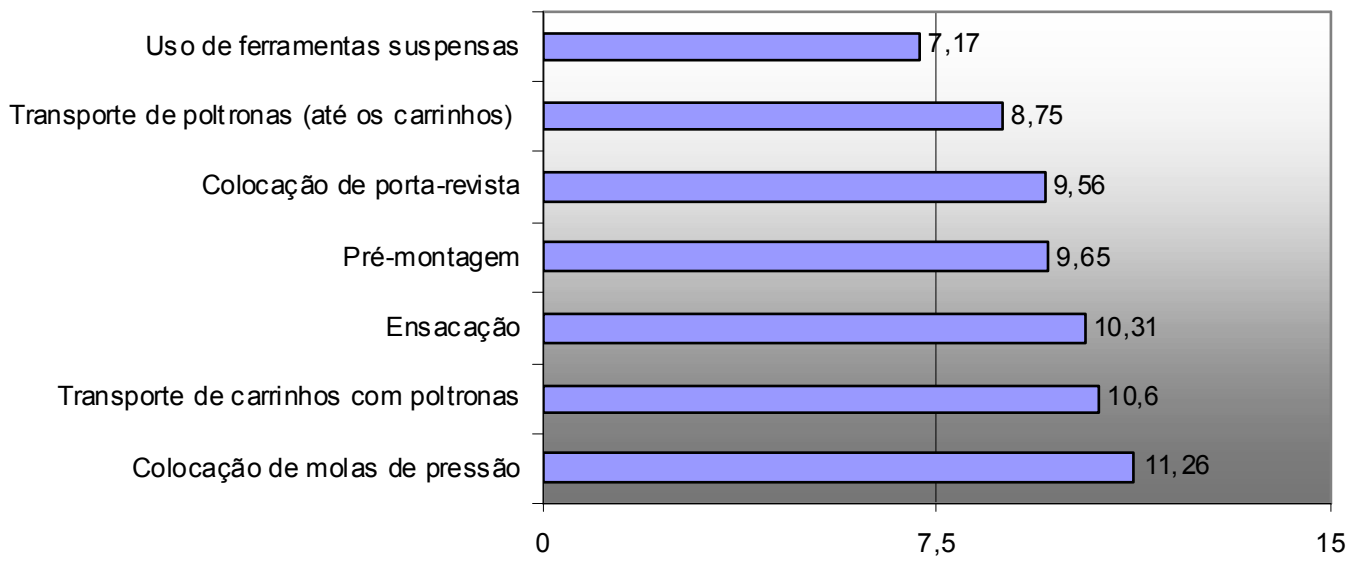

Figura 5 - Resultados dos questionários para o constructo grau de cansaço

Nota: grau de cansaço percebido pelos funcionários $(0=$ nada cansativo, $15=$ muito cansativo $)$

No que diz respeito à percepção quanto aos postos de trabalho (Figura 6), os problemas relativos às ferramentas destacaram-se como os mais críticos, não havendo diferença estatística significativa entre as médias dos mesmos. Além da quantidade insuficiente de ferramentas, a má qualidade de muitas exigia maior esforço físico dos funcionários para realizar suas tarefas (por exemplo, mais força para fixar parafusos) e a desorganização das ferramentas criava conflitos entre funcionários do turno do dia e da noite. Quanto ao constructo meio ambiente (Figura 7), o calor excessivo destacou-se como principal problema, particularmente em duas áreas: junto ao posto de ensacamento, no qual há uma estufa para derreter a cola que fixa as capas dos bancos e no posto de fabricação de assentos, localizado em um mezanino logo abaixo do telhado. 


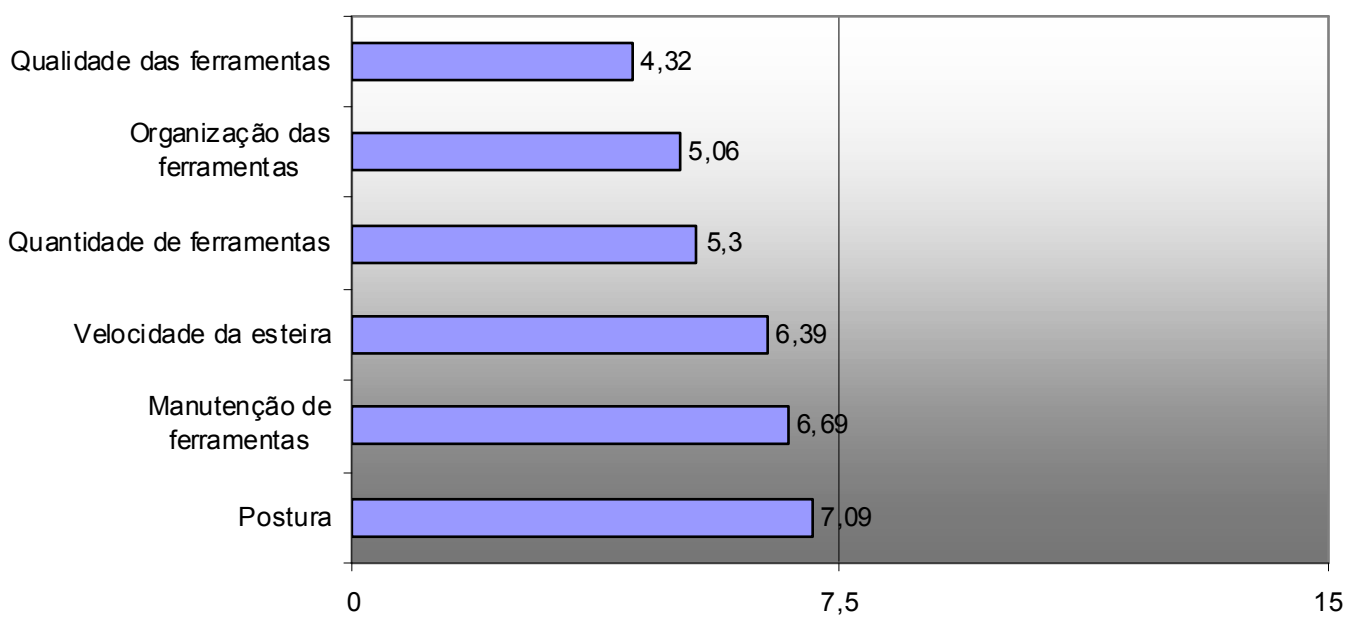

Figura 6 - Resultados dos questionários para o constructo posto de trabalho

Nota: nível de satisfação referente ao posto de trabalho $(0=$ nada satisfeito, $15=$ muito satisfeito $)$

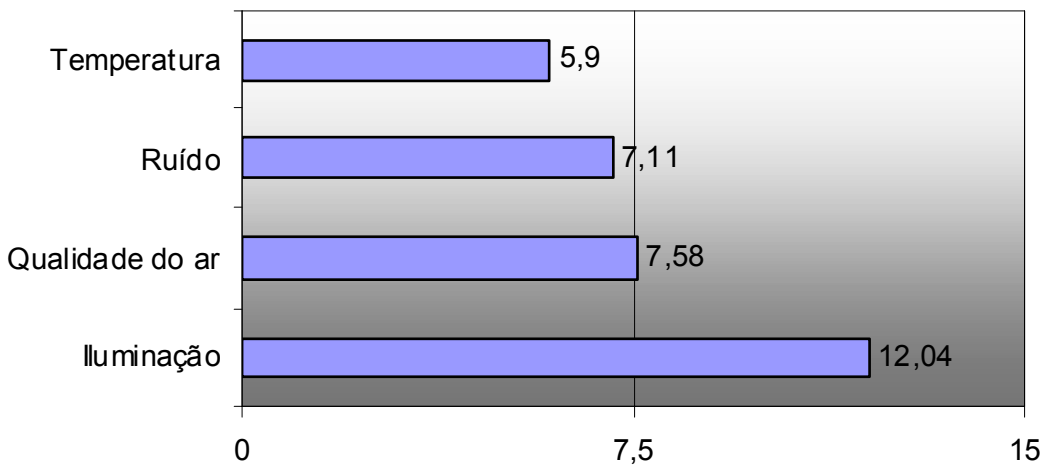

Figura 7 - Resultados dos questionários para o constructo meio ambiente

Nota: nível de satisfação referente ao meio ambiente $(0=$ nada satisfeito, $15=$ muito satisfeito $)$

\subsubsection{Resultados da avaliação da carga física postural}

A Figura 8 apresenta a distribuição das categorias de risco para os postos priorizados, enquanto a Figura 9 ilustra as categorias de risco específicas para o posto de ensacamento. Os resultados não indicaram problemas posturais sérios em nenhum dos postos, havendo preponderância das categorias de risco 1 e 2. Pode-se considerar que a avaliação quantitativa confirma a percepção dos funcionários em relação às posturas adotadas, uma vez que, conforme a Figura 6 (item anterior), embora os funcionários tendam à insatisfação com a postura adotada (7,09 em uma escala de 0 à 15$)$ essa insatisfação não é extrema.

Contudo, nota-se que o posto de ensacamento é o que apresenta as posturas mais desfavoráveis, obtendo o maior percentual de posturas na categoria 2. No ensacamento e na pré-montagem, observouse que a coluna estava curvada e torcida em $13 \%$ das observações, o que se salientou como o principal dado negativo. Já na montagem do assento, salientou-se a necessidade de elevar cargas de até $20 \mathrm{~kg}$ em $23 \%$ do tempo de observação. 


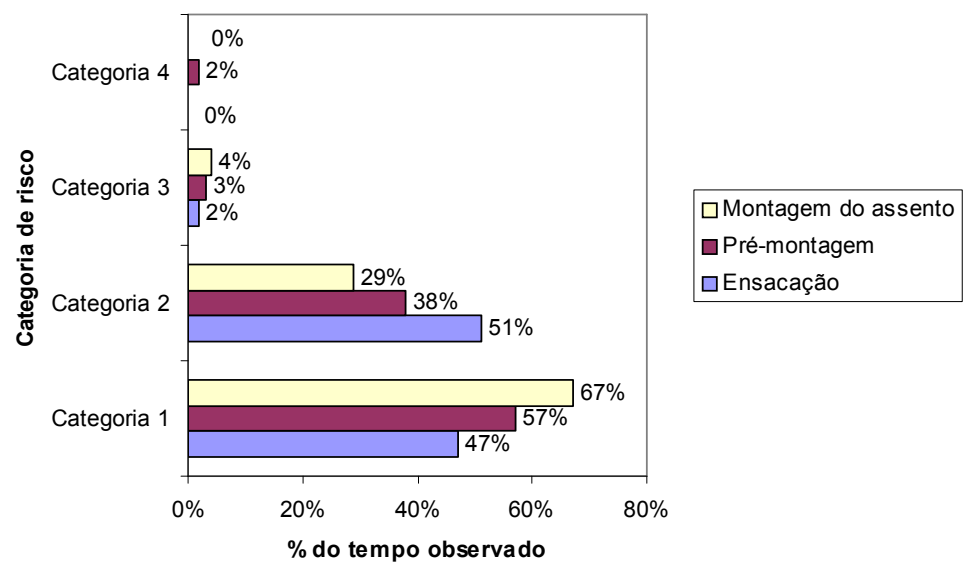

Figura 8 - Distribuição das categorias de risco para os três postos priorizados

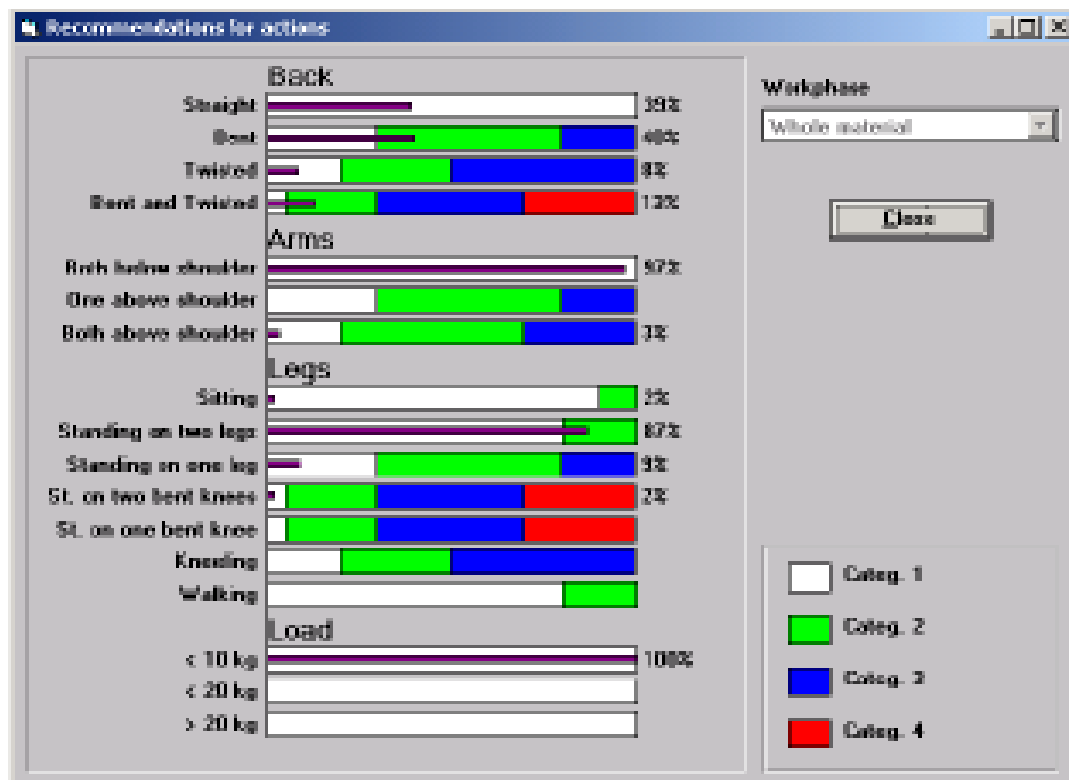

Figura 9 - Categorias de risco para o posto de ensacamento

\subsubsection{Resultados da avaliação da carga fisiológica de trabalho}

A Tabela 2 resume os dados da avaliação de esforço físico nos postos priorizados. Embora existam classificações de trabalho leve, médio ou pesado baseadas em batimentos médios, picos de batimento ou consumo de oxigênio (ASTRAND e RODAHL, 1986), as mesmas não foram utilizadas nesse estudo uma vez que não consideram as características individuais como idade, peso e estado geral de saúde. Tendo em vista minimizar o efeito das características individuais na análise dos dados de FC, o principal parâmetro de análise adotado foi o pulso de trabalho (PT), definido como a diferença entre a freqüência cardíaca média (bpm médio) e a freqüência cardíaca de repouso (pulso em repouso). A literatura não indica faixas de valores de PT classificadas como muito ou pouco desgastantes, mas de acordo com Grandjean (1998), 35 pulsos de trabalho são o limite de trabalho contínuo a ser usado como referência para os homens. Assim, pode-se concluir que os três postos apresentam níveis similares de desgaste físico, abaixo do limite de 35 PT.

O software de análise de dados da freqüência cardíaca apresenta gráficos que indicam a distribuição percentual dos batimentos médios, em faixas, ao longo do período de observação. A partir disso, foi possível estimar a distribuição percentual do pulso médio de trabalho. Por exemplo, no caso da prémontagem, durante $42,9 \%$ do tempo de observação, os batimentos médios por minuto situaram-se na 
faixa de 100 a 110 . Então, pode-se dizer que durante esse período, o pulso de trabalho médio (média do pulso durante o período menos o pulso em repouso) foi de $27(105-78=27)$. A Tabela 3 ilustra a distribuição do pulso médio de trabalho para os postos de ensacamento e pré-montagem. Com base nessa tabela, o posto de ensacamento parece implicar em maior desgaste, uma vez que durante $44,8 \%$ do tempo de observação o PT está bastante próximo ou acima do limite de 35 PT. Já no posto de prémontagem, isso ocorre em $29,9 \%$ do tempo. Essa análise não foi realizada para o posto de montagem de assento, uma vez que o registro da FC foi conduzido sem os recursos computacionais necessários.

Tabela 2. Resumo da avaliação de esforço físico nos três postos priorizados, com base na freqüência cardíaca

\begin{tabular}{l|llll} 
Trabalhador & FC média & Pico FC & Repouso & Pulso de trabalho (PT) \\
\hline Ensacamento & 106 & 130 & 83 & 23 \\
Pré-montagem & 104 & 130 & 78 & 26 \\
Montagem do assento & 86 & 92 & 60 & 26
\end{tabular}

Tabela 3 - Estimativa da distribuição percentual do pulso médio de trabalho

\begin{tabular}{ll|ll} 
Ensacamento & & Pré-montagem & \\
\hline Pulso de trabalho médio & $\%$ do tempo observado & Pulso de trabalho médio & $\%$ do tempo observado \\
2 & $9,2 \%$ & 7 & $10,1 \%$ \\
12 & $12,8 \%$ & 17 & $16,1 \%$ \\
18 & $32,1 \%$ & 27 & $42,9 \%$ \\
32 & $40,9 \%$ & 37 & $26,2 \%$ \\
42 & $3,9 \%$ & 47 & $3,7 \%$
\end{tabular}

Assim como no caso da avaliação postural, novamente pode ser considerado que as percepções dos trabalhadores foram coerentes com a avaliação quantitativa. De acordo com a Figura 6 (item 3.1.3), os trabalhadores apontaram as atividades nos postos priorizados como cansativas, embora os valores não tenham sido extremos (entre 9,65 e 10,6 em uma escala de 0 à 15). Similarmente, a avaliação quantitativa indicou PT preocupantes, embora não tenham ultrapassado o limite indicado na literatura.

\subsection{Montagem de painéis}

\subsubsection{Caracterização do trabalho de montagem de painel}

O layout do setor de montagem dos ônibus pode ser caracterizado como linear (flow shop), havendo quatro linhas de produção subdivididas em diversos postos de trabalho, a maioria dentro do próprio ônibus, onde são montados os seus componentes. Em um desses postos ocorre a montagem dos painéis, constituídos por estruturas ocas onde são colocadas a direção, mostradores, câmbio, pedais, dutos e instalações correspondentes. A montagem de painéis é feita apenas por homens, em turno diurno. Há constante manuseio, transporte e instalação de peças acabadas ou semi-acabadas no painel. $\mathrm{O}$ trabalho é predominantemente manual e pesado, sendo eventualmente realizado com o auxílio de ferramentas pneumáticas e carrinhos transportadores.

\subsubsection{Apreciação e diagnóstico}

O resultado geral dos questionários aplicados na linha de montagem mostrou que o trabalho é satisfatório em quase todos os constructos, à exceção de dois: a) meio ambiente, devido à precária ventilação; b) organização do trabalho, devido à má distribuição das tarefas nos postos de trabalho, ao excesso de funcionários trabalhando ao mesmo tempo dentro do ônibus e ao excesso de esforço físico.

Os resultados da apreciação (resultado das entrevistas e questionários, e da observação direta da montagem) foram discutidos com um grupo de engenheiros e técnicos que compõem o SESMT e o grupo de melhoria contínua da empresa. Decidiu-se, como prioridade inicial para melhorias ergonômicas na linha de montagem, realizar um diagnóstico detalhado e propor melhorias no posto de montagem de painéis. Esse posto era representativo das dificuldades impostas pela montagem dentro do ônibus, tendo sido apontado como um dos mais problemáticos pelos funcionários. Outros dois 
postos também ilustram essas dificuldades: a colocação dos porta-pacotes (bagageiro), estrutura de 12 $\mathrm{m}$ de comprimento inserida no veículo manualmente pela janela frontal do veículo e cuja instalação requer a participação de doze pessoas; a colocação dos assentos para dentro do ônibus, realizada manualmente e pelas janelas laterais. As Figuras 10 e 11 mostram alguns momentos da montagem do chicote do painel (feixe de fiações elétricas), enquanto que as Figuras 12 e 13 mostram detalhes da montagem da parte externa do painel.

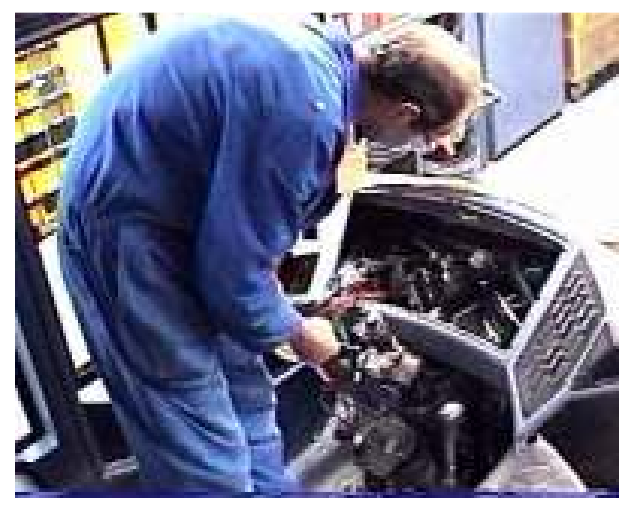

Figura 10. Montagem do chicote do painel

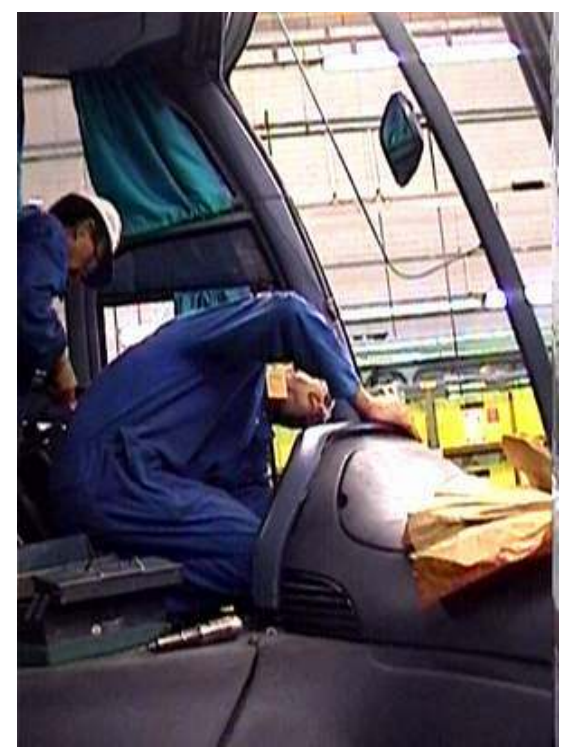

Figura 12. Montagem externa do painel

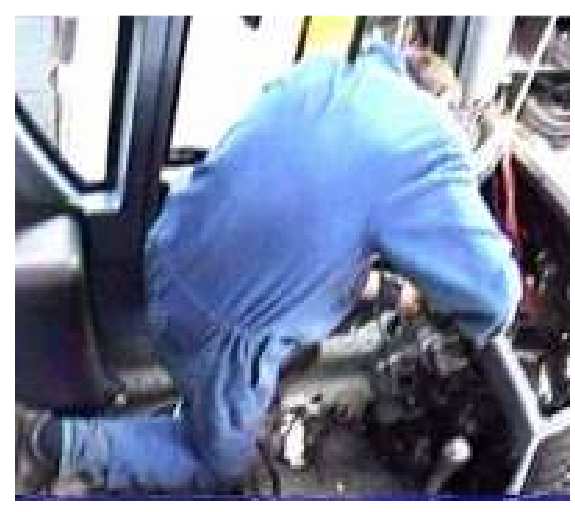

Figura 11. Montagem do chicote do painel (b)

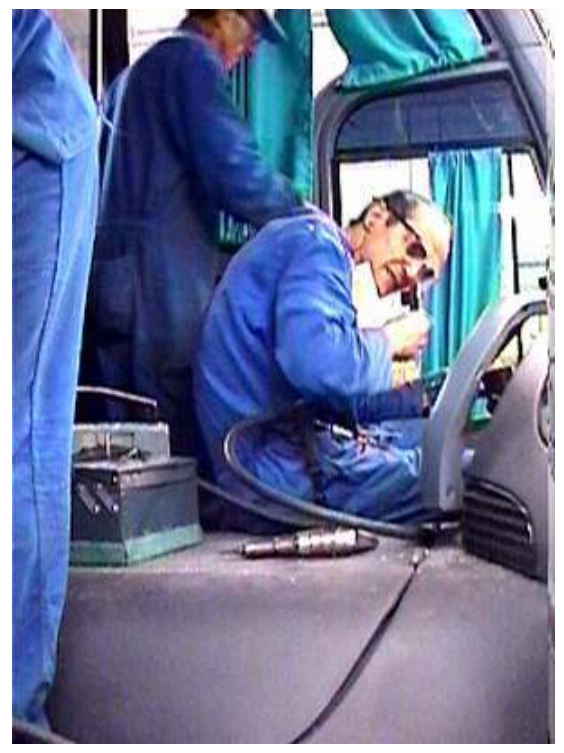

Figura 13. Encaixe da estrutura externa do painel

Os resultados, obtidos com a ferramenta WinOWAS $®$, das posturas assumidas durante o trabalho de montagem de painel totalmente dentro do ônibus, como era usual, são apresentados na Figura 14. Salienta-se, principalmente, as posturas inadequadas das costas (em 56\% das observações estavam curvadas e torcidas) e a necessidade de trabalhar em pé com os joelhos dobrados ( $50 \%$ das observações). Esta sobrecarga física gerada pela adoção de posturas desgastantes é decorrência da característica do posto e da organização do trabalho. Sendo o posto o próprio ônibus, não há espaço para movimentação, e o trabalho de montagem peça a peça acaba sendo prejudicado pelas interferências entre equipes. A insatisfação quanto ao excesso de trabalhadores dentro do ônibus foi bastante ressaltada na fase de apreciação ergonômica. 


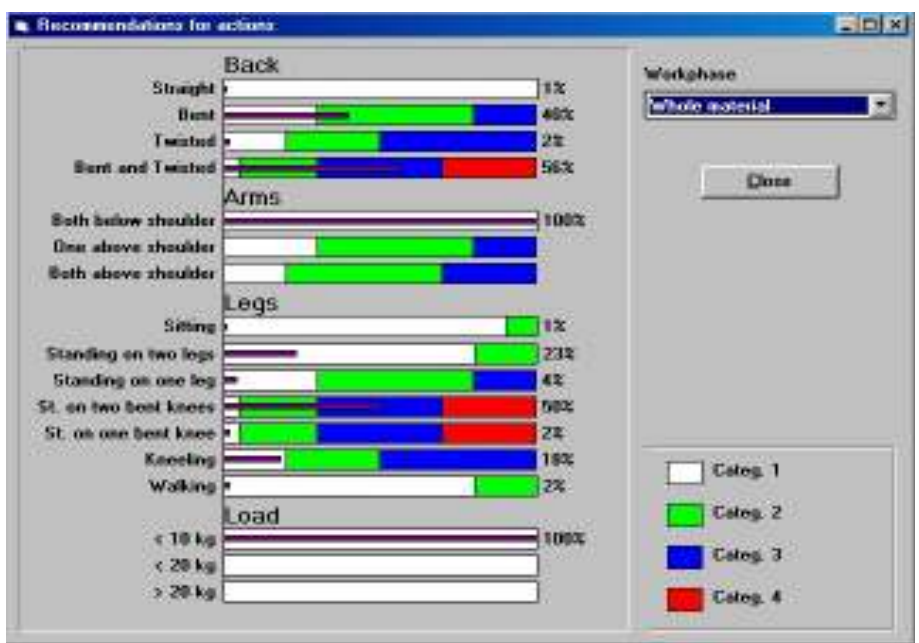

Figura 14 - Resultados da análise postural da montagem do painel, internamente ao ônibus

\section{Proposição de melhorias}

\subsection{Setor de fabricação de poltronas}

A visita à concorrente alemã indicou alternativas de melhoria no setor de poltronas. Inicialmente, a costura das capas poderia ser realizada em um setor específico por meio de máquinas de costura, ao invés de ser realizada na própria linha de modo totalmente manual. Embora a costura mecanizada possa modificar o aspecto estético da capa, as condições de trabalho da atividade de ensacamento seriam melhoradas. A Figura 15 ilustra o posto de trabalho de colocação das capas (já costuradas) na fábrica alemã.

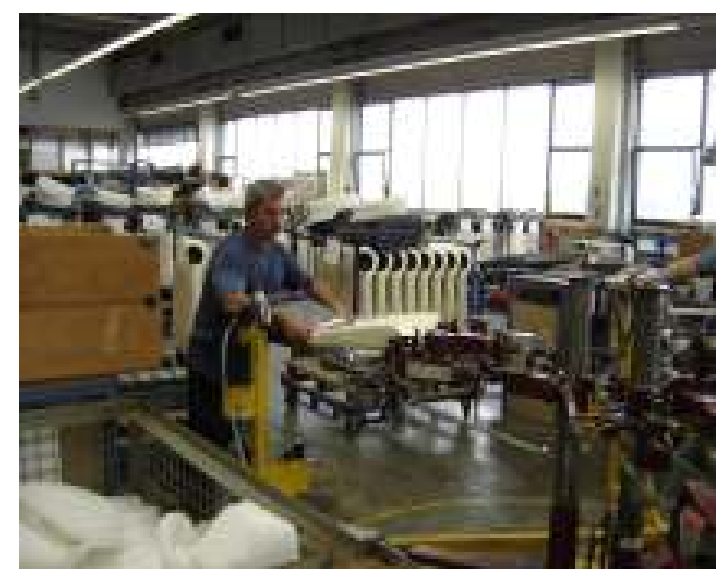

Figura 15 - Posto de trabalho de colocação de capas das poltronas na concorrente alemã

Ainda no setor de poltronas, a fábrica alemã adotava o conceito de manufatura celular (Figura 16), ao invés da linha de montagem adotada na fábrica brasileira. De acordo com esse conceito (HYER e BROWN, 1999) os processos devem estar fortemente conectados em termos de tempo, espaço e informação, o que de fato parecia haver na célula visitada. Nessa célula, oito trabalhadores trabalhavam sobre uma plataforma que girava em intervalos ditados pelo takt time (ritmo de produção necessário para atender a demanda, nesse caso expresso em termos de minutos / poltrona). Cada trabalhador executava todas as atividades do ciclo de montagem, incluindo, dentre outros, a colocação de assentos, cintos de segurança e descansa-braços. Do lado externo da plataforma, eram estocados os materiais necessários a cada atividade, sendo que os materiais existiam apenas em uma posição específica. Deste modo, um eventual atraso de um operador implicaria na paralisação das atividades de todos os membros da equipe, os quais deveriam auxiliar o colega atrasado. 
Em relação ao arranjo da fábrica brasileira, a célula visitada apresentava benefícios em termos de alargamento do trabalho, possibilidade de trabalho em equipe e aparentes melhores posturas dos trabalhadores. Contudo, caberia uma investigação detalhada acerca dos efeitos deste arranjo em termos de estresse dos trabalhadores. A dependência rígida entre o desempenho de todos os membros da equipe pode ser um fator de pressão psicológica e conflitos de relacionamento. Uma opção que eliminaria este problema seria a criação de um layout de posição fixa, no qual cada trabalhador realizaria todas as atividades de montagem da poltrona. Contudo, nesse caso haveria o incoveniente de maior dificuldade para abastecer os mesmos materiais em diversos postos de trabalho.

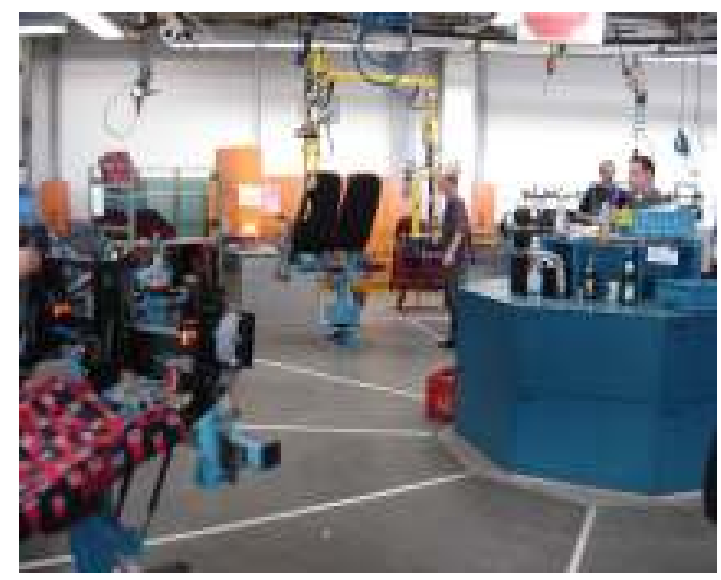

Figura 16 - Célula de montagem de poltronas na fábrica alemã

A minimização de esforço físico no transporte de poltronas também envolve mecanização. Neste sentido, a fábrica alemã também apresentava uma solução interessante (Figura 17). Nesse caso, as poltronas eram montadas em um pavimento superior ao da linha de montagem, sendo transportadas por meio de um trilho suspenso no teto até um elevador localizado muito próximo ao posto de trabalho da linha no qual as poltronas seriam colocadas dentro do ônibus. Ao chegarem no nível da linha de montagem, as poltronas (armazenadas em um carrinho) eram retiradas por um operário que encaminhava a mesma para dentro do ônibus através de outro trilho localizado na janela frontal do veículo. Na fábrica brasileira, na época em que o estudo foi realizado, a colocação das poltronas era feita manualmente por dois operadores (um dentro e outro fora do ônibus), através das janelas laterais do veículo.
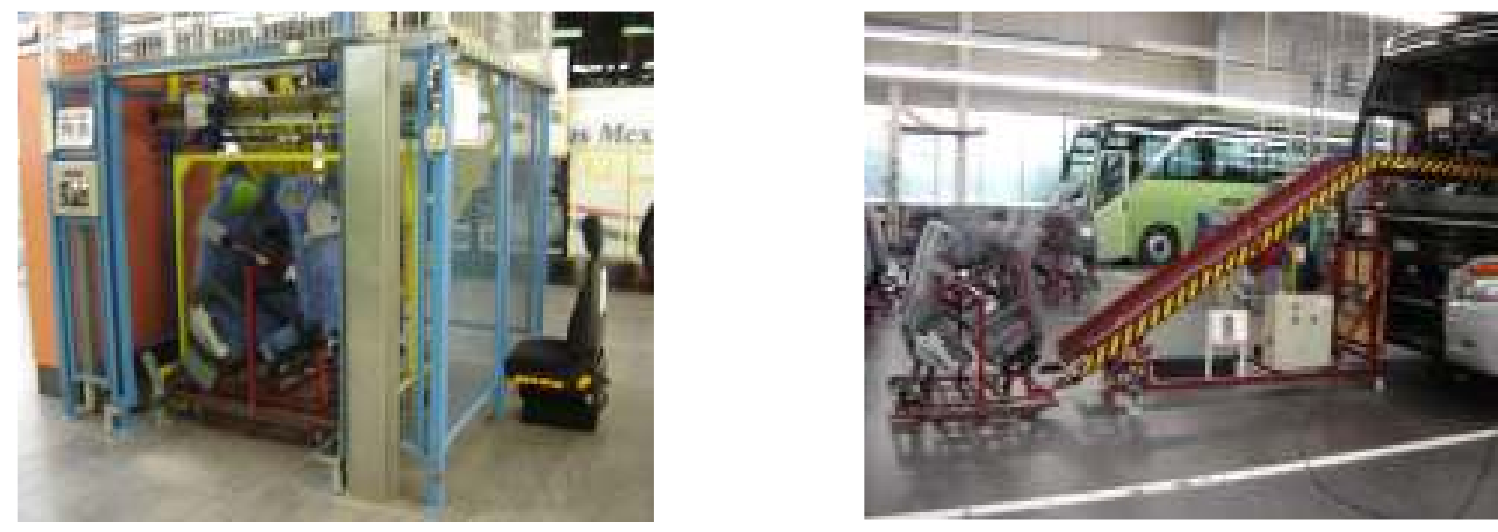

Figura 17 - Transporte de poltronas na fábrica alemã (à esquerda: elevador para transporte desde a área de montagem das poltronas no pavimento superior até a linha de montagem; à direita: trilho de acesso ao interior do veículo) 
De outra parte, como alternativa intermediária, poderia ser colocada uma talha com o objetivo de transportar as poltronas desde a esteira até os carrinhos de estoque. Nesse caso, o transporte dos carrinhos até o pátio externo seria realizado por veículos rebocadores. Quanto ao posto de prémontagem, percebeu-se que problemas de qualidade nos perfis metálicos são responsáveis, em parte, por esforços desnecessários. Os trabalhadores da pré-montagem necessitam ajustar as dimensões dos perfis em pontos específicos por meio de fortes marteladas no mesmo. Embora não tenha sido feito um diagnóstico detalhado no posto de colocação de molas de pressão na base do assento, os resultados dos questionários indicaram que as tarefas realizadas no mesmo também são cansativas. A redução de esforço físico pode ser obtida por meio do reprojeto da mola, de modo que o seu encaixe na estrutura do banco seja facilitado. Uma vez que atualmente três molas individuais são colocadas em cada assento, está em estudo a possibilidade de uso de uma mola única, reduzindo o número de encaixes.

\subsection{Montagem de painéis}

A melhoria das condições de trabalho foi buscada pela adoção de posturas mais adequadas e pela ampliação de espaço para movimentação. Assim, foi proposta, e testada, a pré-montagem do painel externamente ao ônibus, em bancadas específicas (Figura 18). Cabe ressaltar que a mesma solução também foi constatada na fábrica alemã visitada, a qual também realizava de modo mais racionalizado a tarefa de instalar o porta-pacotes, já citado como outro posto problemático na linha de montagem. As dimensões das bancadas testadas foram as seguintes: $0,8 \mathrm{~m}$ (largura) x 2,58 m (comprimento) x 0,69 m (altura). Uma vez pré-montado, o painel seria transportado manualmente, ou com auxílio de equipamentos, para dentro do ônibus e devidamente fixado na sua posição definitiva. Desta maneira, reduz-se o tempo de trabalho dentro do ônibus e as respectivas posturas inadequadas.

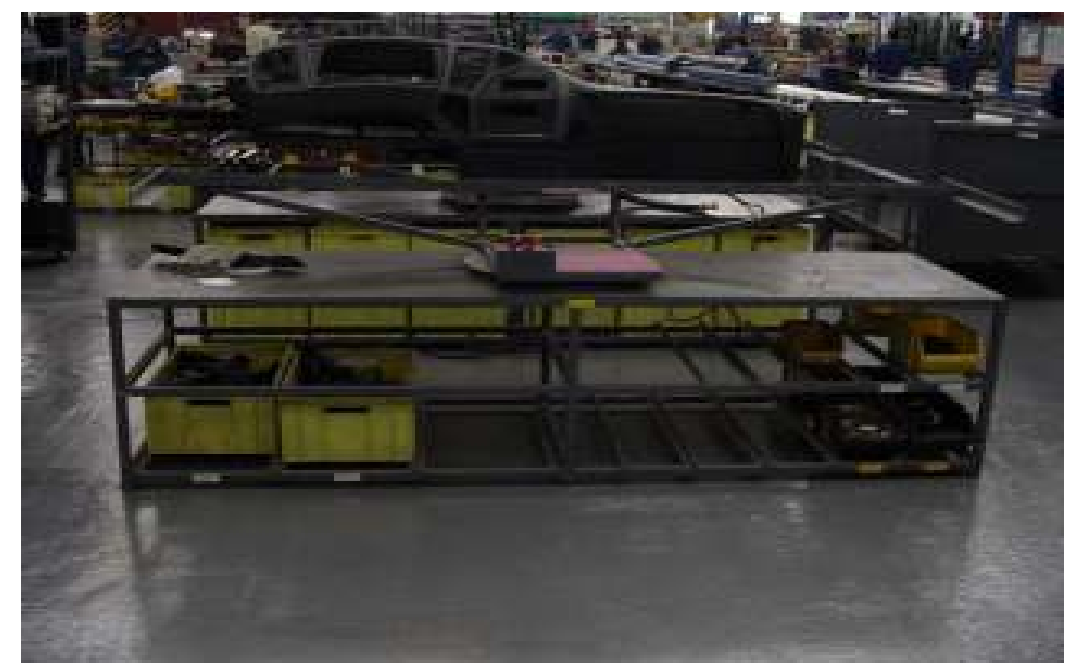

Figura 18 - Bancada testada para a pré-montagem externa do painel

\section{Avaliação do novo posto de montagem de painéis}

A avaliação das posturas na nova situação de trabalho ocorreu em dois momentos: a) pré-montagem sobre a bancada; b) colocação do painel pré-montado na posição final dentro do ônibus e montagem final. A Figura 20 apresenta os resultados da avaliação postural na tarefa de pré-montagem sobre a bancada, enquanto a Figura 17 apresenta os resultados da colocação do painel pré-montado na posição final dentro do ônibus. No sistema de pré-montagem sobre a bancada, as costas permanecem mais tempo na posição ereta (48\%), e muito pouco tempo na posição mais prejudicial, curvada e torcida $(7 \%)$. A postura das pernas também melhora, pois no novo sistema sobre a bancada o funcionário se ajoelha (pior situação) em apenas 3\% do tempo contra 18\% no sistema usual (ver Figura 14). 


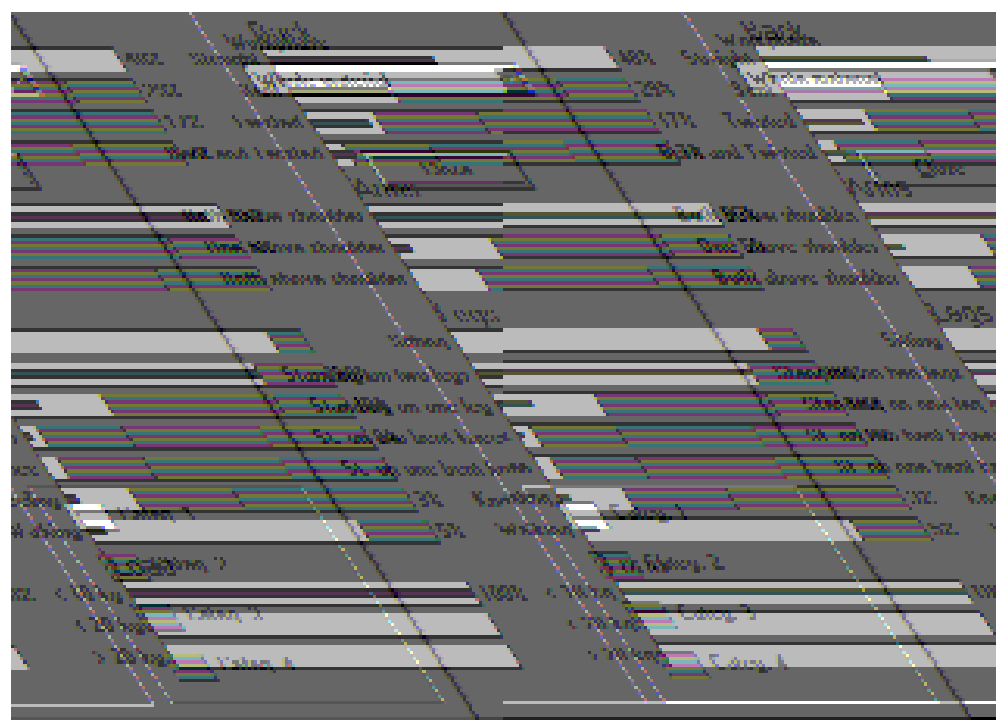

Figura 19 - Resultados da análise postural na pré-montagem externa ao ônibus

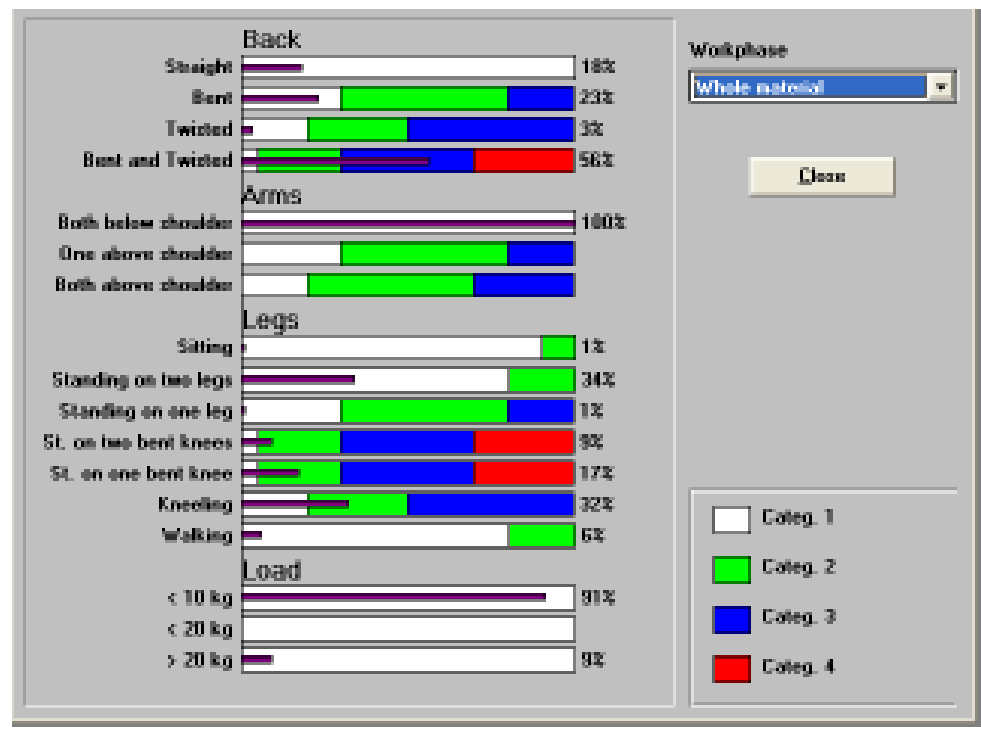

Figura 20 - Resultados da análise postural na colocação do painel pré-montado dentro do ônibus

Entretanto, a comparação entre as Figuras 19 e 20 indica que a montagem em bancada externa é o que traz maior ganho no novo sistema proposto, uma vez que a colocação do painel pré-montado dentro do ônibus ainda traz constrangimentos sérios, principalmente para as costas (em $56 \%$ do tempo curvadas e torcidas) e as pernas (em 32\% do tempo ajoelhadas).

A Tabela 4 mostra que o trabalho de montagem do painel peça a peça dentro do ônibus enquadra-se na categoria de ação 4 (maior risco) em 32\% das observações; na categoria de ação 3 em 29\%; na categoria de ação 2 em 38\% e na categoria 1 (postura normal, sem risco) em apenas 1\%, o que corrobora a preocupação do SESMT em atuar imediatamente nesta tarefa. Contudo, a pré-montagem externa reduziu a carga física sobre o montador, já que uma maior parcela do trabalho ( $35 \%$ no novo sistema contra apenas $1 \%$ no antigo) está agora na categoria 1 . Apesar disto, ainda permanece o mesmo percentual de trabalho na categoria 4 , em função da atividade de instalação do painel prémontado dentro do ônibus. O cálculo da distribuição final das posturas por categoria de risco na nova situação levou em conta os tempos de trabalho sobre a bancada e dentro do ônibus (ver Tabela 5). 
Além do ganho em função da minimização de posturas desgastantes, houve também um ganho de produtividade. Um comparativo entre a produtividade nos dois sistemas (Tabela 5) demonstra que houve um ganho de 7,2\% devido à pré-montagem externa do painel. Entretanto, cabe ressaltar que esses dados correspondem apenas a um teste realizado, sendo necessárias medições adicionais para confirmação deste benefício.

Tabela 4 - Comparação das posturas no sistema usual de montagem de painel dentro do ônibus, e na nova situação de pré-montagem externa

\begin{tabular}{|l|l|l|l|l|}
\hline & $\begin{array}{l}\text { Montagem toda } \\
\text { dentro do ônibus }\end{array}$ & $\begin{array}{l}\text { Pré-montagem } \\
\text { fora do ônibus }\end{array}$ & $\begin{array}{l}\text { Colocação do painel } \\
\text { pré-montado }\end{array}$ & $\begin{array}{l}\text { Final nova } \\
\text { situação }\end{array}$ \\
\hline Categoria 1 & $\mathbf{1 \%}$ & $64 \%$ & $20 \%$ & $35 \%$ \\
\hline Categoria 2 & $\mathbf{3 8} \%$ & $34 \%$ & $23 \%$ & $27 \%$ \\
\hline Categoria 3 & $\mathbf{2 9} \%$ & $1 \%$ & $8 \%$ & $6 \%$ \\
\hline Categoria 4 & $\mathbf{3 2} \%$ & $1 \%$ & $49 \%$ & $32 \%$ \\
\hline
\end{tabular}

Tabela 5 - Produtividade na situação de montagem usual e na proposta de pré-montagem externa

\begin{tabular}{|l|l|}
\hline & Tempos \\
\hline Montagem toda dentro do ônibus & $7,78 \mathrm{~h} /$ pessoa \\
\hline Pré-montagem fora do ônibus & $2,45 \mathrm{~h} /$ pessoa \\
\hline Colocação do painel pré-montado & $4,77 \mathrm{~h} /$ pessoa \\
\hline Final nova situação & $7,22 \mathrm{~h} /$ pessoa \\
\hline Diferença & $\mathbf{0 , 5 6} \mathbf{h} /$ pessoa $\mathbf{( 7 , 2 \% )}$ \\
\hline
\end{tabular}

Cabe mencionar que parte das posturas inadequadas parece ser inevitável com as atuais tecnologias, layout interno do ônibus e seqüenciamentos, uma vez que o painel situa-se abaixo do nível do piso de trabalho e é colocado após a instalação da carroceria. Contudo, as seguintes ações são sugeridas para futuros testes:

a) na filmagem da tarefa, observou-se que o transporte do painel pré-montado desde a bancada até o ônibus foi feito manualmente por duas pessoas e, ao chegar junto ao ônibus, o painel foi colocado no piso, sendo executadas tarefas nessa situação ao longo de cerca de cinco minutos. Desse modo, deve ser estudada a localização da área de pré-montagem junto aos ônibus, reduzindo a necessidade de transporte. Contudo, ainda assim é pertinente a mecanização do transporte do painel para dentro do ônibus, tarefa de grande dificuldade. Caso a área de pré-montagem permaneça distante do ônibus, deve ser colocada uma nova bancada de trabalho junto aos mesmos, evitando a colocação do painel no piso e a realização de trabalhos nesse nível;

b) deve ser priorizada a identificação de outras atividades que possam ser realizadas fora do ônibus na pré-montagem sobre a bancada, especialmente às relacionadas à furação e aparafusamento do painel, identificadas como críticas em termos posturais. O objetivo deve ser reduzir ainda mais o tempo de trabalho dentro do ônibus;

c) a bancada de pré-montagem também requer modificações. Inicialmente, a mesma deve possuir altura ajustável, uma vez que o objeto de trabalho possui diversos modelos e tem altura e forma irregular. Além disso, foi observada a realização de trabalho na postura ajoelhada ( $3 \%$ do tempo) para colocação de componentes nas laterais do painel. A plataforma, idealmente, deve permitir o giro sobre seu eixo horizontal. O giro sobre o eixo vertical, como foi testado, não traz benefícios práticos. Já o giro proposto tende a facilitar o acesso das mãos e braços do operador ao interior do painel por meio de suas aberturas. A maior parte das posturas torcidas das costas ocorreu quando o operador necessitou acessar essas aberturas para ajuste de componentes internamente. Também deve ser considerada a hipótese desses componentes serem colocados pré-montados dentro do painel, reduzindo a necessidade de acesso. 
Os materiais necessários à montagem não devem ser estocados embaixo da bancada, visto que isso obriga o operador a posturas inadequadas. Tais materiais poderiam ser estocados em armários ao lado da bancada. A necessidade de buscar materiais em locais distantes foi o fato responsável pelo operador gastar 5\% do tempo caminhando na nova situação. Além disso, a bancada também deve possuir espaço para colocação de uma caixa de ferramentas e uma lixeira ao seu lado, reduzindo deslocamentos do operador.

\section{Conclusões}

Este trabalho apresentou os resultados de uma intervenção ergonômica em uma fábrica de ônibus urbanos e rodoviários no Rio Grande do Sul. No setor de fabricação de poltronas, três postos de trabalho foram selecionados para diagnóstico e proposição preliminar de melhorias: colocação de capas nas poltronas (ensacamento), montagem da estrutura metálica da poltrona (pré-montagem) e montagem do assento. No posto de ensacamento, a atividade de costura manual das capas dos bancos está fortemente associada aos problemas posturais e ao desgaste físico, sendo proposto que as capas sejam costuradas por meio de máquinas de costura fora da linha de montagem. Similarmente, a mecanização do transporte das poltronas parece ser necessária para reduzir o esforço físico intenso e a baixa produtividade nessa tarefa.

$\mathrm{Na}$ linha de montagem final dos veículos, a intervenção teve como foco a atividade de montagem de painéis, a qual era realizada inteiramente dentro do veículo e possuía sérios constrangimentos posturais. Foi implementada uma bancada para pré-montagem de painéis externamente ao ônibus, com vistas a reduzir as posturas inadequadas. A análise de posturas por meio do método OWAS mostrou que a utilização da bancada minimiza os constrangimentos, principalmente nas costas e pernas do montador. Além disso, a análise de tempos durante um teste do novo sistema indicou redução do tempo total de montagem na ordem de $7 \%$, por operador. Espera-se que, na medida em que os trabalhadores aprendam o novo sistema de montagem de painéis e o setor de submontagem seja otimizado, os ganhos sejam ainda maiores.

A visita a uma fábrica alemã concorrente da fábrica brasileira na qual ocorreu o estudo contribuiu para a identificação de propostas de melhoria. Em particular, ficou notório que a fábrica alemã primava pela mecanização das tarefas que exigiam grande esforço físico, associada a alternativas otimizadas de layout.

\section{Referências}

ASTRAND, P.; RODAHL, K. Textbook of work physiology, physiological bases of exercise. New York: McGraw-Hill, 1986, 3.ed.

GRANDJEAN, E. Manual de ergonomia: adaptando o trabalho ao homem. Porto Alegre: Artes Médicas, 1998, 4. ed.

GUIMARÃES, L.B. Ergonomia de Processo. Porto Alegre: Programa de Pós-Graduação em Engenharia de Produção, Universidade Federal do Rio Grande do Sul, 1999, 3.ed.

HENDRICK, H.; KLEINER, B. Macroergonomics: an introduction to work system design. Santa Monica: Human Factors and Ergonomics Society, 2001.

HYER, N.; BROWN, K. The discipline of real cells. Journal of Operations Management, v. 17, p. 557-574, 1999.

INSTITUTO NACIONAL DE PREVIDÊNCIA SOCIAL (INSS). Relatório de Pagamento de Benefícios concedidos. Brasília, 1986. 
KARHU, O. KANSI, P.; KUORINKA, I. Correcting working postures in industry: a practical method for analysis. Journal of Applied Ergonomics, v.8, n.4, p.199-201, 1977.

KIVI, P.; MATILLA, M. Analysis and improvement of work postures in the building industry: application on the computerized OWAS method. Journal of Applied Ergonomics, v.22, n.1, p. 43-48, 1991.

LAGERLOF, L. Occupational Ergonomics: work related musculoskeletal disorders of the upper limb and back. New York: Taylor and Francis, 2000.

MARTIN-VEGA, L.A.; BROWN, H.K.; SHAW, H.; SANDERS, T.J. Industrial perspective on research needs and opportunities in manufacturing assembly. Journal of Manufacturing Systems; v.14, n.1, 1995.

RAMPERSAD, H.K. Integrated and Simultaneous Design for Robotic Assembly. John Wiley \& Sons, 1994.

RASMUSSEN, J. Risk management in a dynamic society: a modeling problem. Safety Science, v. 27, n. 2/3, p. 183-213, 1997.

STONE, H.; SIDEL, J.; OLIVER, S.; WOOLSEY, A.; SINGLETON, R.C. Sensory evaluation by quantitative descriptive analysis. Food Technology. V.28, n.1, p.24-34, 1974. 